\title{
Testis morphology in rats chronically treated with letrozole, an aromatase inhibitor
}

\author{
Anna Kondarewicz', Agnieszka Kolasa', Bartosz Zawiślak ${ }^{1}$, \\ Irena Baranowska-Bosiacka ${ }^{2}$, Mariola Marchlewicz ${ }^{1}$, \\ Lidia Wenda-Różewicka1, Barbara Wiszniewska ${ }^{1}$ \\ ${ }^{1}$ Department of Histology and Embryology, Pomeranian Medical University in Szczecin, Poland \\ ${ }^{2}$ Department of Biochemistry and Human Nutrition, Pomeranian Medical University \\ in Szczecin, Poland
}

\begin{abstract}
The aim of this study was to investigate the influence of the long-term treatment of rats with letrozole on the testis morphology. The pharmacologically induced estrogen deficiency caused statistically significant decreases of both intratesticular and serum levels of estradiol, and morphological changes in the seminiferous epithelium and in the interstitial tissue of the testes. Six months of treatment resulted in the sloughing of premature germ cells of the seminiferous epithelium into the tubular lumen and in intraepithelial vacuolization. Multinucleated giant cells composed of premature germ cells, conglomerates of various cell nuclei and cell debris as well as irregularities and infoldings of the tubular basement membrane were also seen. Moreover, deep invaginations of the lamina propria with myoid cells were observed. Cells in the interstitial tissue showed changes similar to that observed in aging processes. The cytoplasm of LH-R-positive Leydig cells was loaded with lipofuscin granules. The number of lipofuscin-loaded cells was significantly increased in the interstitial tissue of testis in letrozole-treated rats. The results indicate the direct influence of estrogens on seminiferous tubules and the interstitial tissue morphology. (Folia Histochemica et Cytobiologica 2011; Vol. 49, No. 4, pp. 677-684)
\end{abstract}

Key words: letrozole, cytochrome P450, aromatase, testis, rat

\section{Introduction}

The testis performs two essential functions: the production of spermatozoa in the spermatogenesis process and the synthesis of steroids in interstitial Leydig cells, involved in the secretion of testosterone and other steroids including estrogens [1]. The major endocrine regulators of testis functions are gonadotropins. Luteinizing hormone stimulates synthesis and secretion of testosterone in Leydig cells that express LH receptors (LH-R). FSH targets Sertoli cells to stimulate their function to maintain the spermatogenesis. Today it is known that as well as androgens,

Correspondence address: A. Kondarewicz,

Department of Histology and Embryology,

Pomeranian Medical University in Szczecin,

Powstancow Wielkopolskich Str. 72, 70-111 Szczecin, Poland;

e-mail: anna_kondarewicz@wp.pl estrogens are also included in the regulation of spermatogenesis, spermatozoa differentiation and normal fertility [2-7]. Treatment with estradiol induces spermatogenesis in hypogonadal mice congenitally lacking gonadotropin and thus, sex steroid production [8-10]. Furthermore, estrogens prevent apoptosis of germ cells within human seminiferous tubules in vitro [11].

Estrogens are formed from androgens in the reaction catalyzed by cytochrome $\mathrm{P} 450$ aromatase (P450arom). The key enzyme for estrogens biosynthesis is responsible for irreversible aromatization of androstenedione and testosterone into estrogens $[12,13]$. P450arom is the member of the cytochrome $\mathrm{P} 450$ gene superfamily, and is a product of transcription of a single copy of the Cyp19 gene. In humans, this is located on chromosome 15 [13-15], in rats on chromosome 8, and in mice on chromosome 9 [16]. The enzyme is a microsomal complex composed of two 
proteins: specific heme-glycoprotein cytochrome $\mathrm{P} 450$ aromatase, which contains a steroid binding pocket, and ubiquitous NADPH-cytochrome $\mathrm{P} 450$ reductase $[13,14]$. It is known that aromatase is widely distributed in the testes of mammals, including humans $[14,15]$. In adult men, transcripts of aromatase are found in Leydig cells and Sertoli cells [13]. Latest studies have proved that human and animal germ cells within the seminiferous epithelium also have the ability to convert androgens into estrogens $[14,17]$. In the seminiferous epithelium of adult rats, P450arom transcripts have been detected in spermatocytes and spermatids, while the enzyme activity was more intense in haploid germ cells, especially in the elongated spermatids [13]. Additionally, the presence of P450arom has been found in animal spermatozoa [18] and ejaculated spermatozoa from healthy men, with stronger intensity in the cells containing cytoplasmic droplets [14].

Estrogens exert their cellular effects via estrogen receptors (ERs) widely distributed throughout the male genital tract [13]. The importance of estrogen in the male reproductive system is supported by reports of testicular anomalies in men with mutations in aromatase gene and lacking a functional $\operatorname{ER} \alpha$ [19-22], and studies of mice that lack a functional aromatase gene (ArKO) or $\alpha$ - and $\beta$-estrogen receptors ( $\alpha$ ERKO and $\beta$ ERKO) [23].

The aim of this present study was to investigate the effect of long-term (six months) estrogen deficiency on the testis morphology in adult male rats. To produce the estrogen deficiency, we used letrozole, a non-steroidal inhibitor of P450arom, which inhibits the enzyme by reversible competition.

\section{Material and methods}

The studies were performed on three-month old sexually mature male Wistar rats. The rats were maintained under standard conditions of lighting (12L:12D) and nutrition. The animals were randomly divided into a control group and an experimental group (six rats per group). The rats in the experimental group received per os letrozole (Femara ${ }^{\circledR}$; Novartis Pharma, Germany) - non-steroidal inhibitor of cytochrome P450 aromatase (P450arom) at a dose of $1 \mathrm{mg} / \mathrm{kg}$ b.w./day for six months. After the treatment, animals were sacrificed under Thiopental (Biochemie GmbH, Austria) anesthesia (120 mg/kg b.w., i.p.). Then the testes were immediately taken, fixed in Bouin's fluid and embedded in paraffin. For the morphological analysis, serial sections of testes were stained with PAS methods, toluidine blue and van Gieson [24].

The number of cells with lipofuscin granules was estimated in ten randomly chosen areas of interstitial tissue in the gonads of control and letrozole-treated rats.
Immunohistochemical study. To identify Leydig cells in the interstitial tissue, we carried out an immunohistochemical (IHC) reaction with specific anti-LH-R antibody (Santa Cruz Biotechnology, Santa Cruz, CA, USA; cat. no. sc-25828; final dilution 1:100). The deparaffinized sections were microwaved in citrate buffer $(\mathrm{pH}$ 6.0) for heat-induced epitope retrieval. After slow cooling to room temperature, the slides were washed in PBS twice for $5 \mathrm{~min}$ and then incubated for 60 min with primary anti-LH-R antibody. Next, one part of the slides were stained using the avidin-biotin-peroxidase system with diaminobenzidine as the chromogen (EnVision ${ }^{+}$System-HRP (DAB); Code K4010 DakoCytomation, Glostrup, Denmark) in accordance with the manufacturer's staining protocol. The sections were washed in distilled $\mathrm{H}_{2} \mathrm{O}$ and counterstained with hematoxylin. As a negative control, the specimens were processed in the absence of the primary antibody. Positive staining was defined by visual identification of brown pigmentation using a light microscope.

Following primary antibody incubation, the second part of the slides were incubated with biotinylated secondary anti-rabbit antibody from goat (Vector Laboratories, Burlingame, CA, USA; cat. no.: BA-1000) at final dilution 1:100 for $30 \mathrm{~min}$. The last step of the reaction was the treatment of slides with Alexa Fluor-streptavidin complex (streptavidin, Alexa Flour ${ }^{\circledR} 488$ conjugate, Molecular Probes, Eugene, OR, USA; cat. no.: S11223) at a final dilution 1:50 for 30 min. PBS-washed sections were evaluated using a confocal microscope (FV500, Olympus, Germany). Moreover, deparaffinized and unstained slides of rat testes were estimated in fluorescent microscopy (Zeiss, Axioscop, Germany) to detect the autofluorescence of a lipofuscin.

Hormone levels. In the blood serum of the control and letrozole-treated rats, the concentration of $17 \beta$-estradiol (E2) was determined using the electroluminescence (ECLIA - Electrochemiluminescence Immunoassay) method (Cobas 6000 analyzer, Roche, Switzerland). Some of the sampled testes were used to prepare tissue homogenates. The tissues, frozen in liquid nitrogen, underwent homogenization using a hammer mill, then equal volumes of tissues were sampled, placed in $500 \mu \mathrm{L} 0.9 \% \mathrm{NaCl}$ and homogenized using CAT X120 homogenizer (Germany). The homogenates were centrifuged for $10 \mathrm{~min}$ at $12,000 \mathrm{G}$ at $4^{\circ} \mathrm{C}$. Supernatants were used to determine the estradiol level.

Ethical issue. The experiment was conducted in full accordance with Polish law and with the approval of the ethics committee of the Pomeranian Medical University (Szczecin, Poland; approval no. BN-05/07).

Statistical analysis. Results are expressed as median (M), lower and upper quartile (Q1-Q3). Nonparametric Mann-Whitney U test was used to check significance of differenc- 
Table 1. The concentration of $17 \beta$-estradiol (E2) in the serum and testis homogenates of control rats and rats treated with letrozole

\begin{tabular}{|l|c|c|c|c|}
\hline \multirow{2}{*}{} & \multicolumn{2}{|c|}{ Estradiol (E2) [pg/mL] } & \multicolumn{2}{c|}{ Testes } \\
& \multicolumn{1}{|c|}{$\begin{array}{c}\text { Entrad }(\mathbf{C}) \\
\mathbf{n}=\mathbf{5}\end{array}$} & $\begin{array}{c}\text { Letrozole } \\
\mathbf{n = 5}\end{array}$ & $\begin{array}{c}\text { Control } \\
\mathbf{n}=\mathbf{5}\end{array}$ & $\begin{array}{c}\text { Letrozole } \\
\mathbf{n}=\mathbf{5}\end{array}$ \\
\cline { 2 - 5 } & 55.32 & 28.2 & 40.1 & 22.9 \\
\hline Q1-Q3 & $53.7-56.7$ & $25.63-38.49$ & $38.1-42.39$ & $18.2-23.93$ \\
\hline $\mathrm{X} \pm \mathrm{SD}$ & $54.74 \pm 8.72$ & $31.2 \pm 12.29$ & $40.54 \pm 4.43$ & $20.94 \pm 5.15$ \\
\hline & & vs. C* & & vs. C** \\
\hline
\end{tabular}

$\mathrm{M}$ - median; Q1-Q3 - lower-upper quartiles; $\mathrm{X} \pm \mathrm{SD}-$ mean $\pm \mathrm{SD}$; vs. — versus; asterisks indicate statistically significant differences in Mann-Whitney U test: ${ }^{*} \mathrm{p}<0.05,{ }^{* *} \mathrm{p}<0.01$

es between experimental and control groups. The value of $\mathrm{p}<0.05$ was considered to indicate statistically significant differences. The normality test has been performed by Shapiro-Wilk test. Calculations were done using the software package Statistica 6.1.

\section{Results}

\section{Hormone levels}

The level of E2 in the blood of rats receiving letrozole $(31.2 \pm 12.29 \mathrm{pg} / \mathrm{mL})$ was significantly $(\mathrm{p}<0.05)$ lower than in the control $(54.74 \pm 8.72 \mathrm{pg} / \mathrm{mL})$. A significant difference in intratesticular E2 concentration was also found between the experimental $(20.94 \pm 5.15 \mathrm{pg} / \mathrm{mL})$ and control rats $(40.54 \pm 4.43$ $\mathrm{pg} / \mathrm{mL})(\mathrm{p}<0.001)$ (Table 1$)$.

\section{Morphology of testis}

The testis of control rats presented the normal morphology. The seminiferous epithelium contained all generations of the germ cells, corresponding to the stages of the seminiferous epithelium cycle (Figure 1A). The chronic treatment of rats with letrozole resulted in the morphological changes in the seminiferous epithelium. Some tubules showed the disorganization of the seminiferous epithelium. In the lumen of the tubules in experimental rats, the clusters of sloughed germinal cells, including spermatids and late pachytene spermatocytes were observed (Figure 1B, red arrow). Discontinuous germ cell layers forming the irregular intercellular spaces as the effect of the premature germ cells sloughing (Figure 1B, black arrows) were also noticed. Moreover, intraepithelial vacuoles of varying sizes in the basal region of the seminiferous epithelium were found (Figure 1C, black arrows). In gonads of rats chronically treated with letrozole, tubules with multinucleated giant cells, con- taining nuclei of spermatogonia and spermatocytes within the seminiferous epithelium (Figure 1D, red arrows) were detected. Additionally, conglomerates with difficult to identify degenerating cells were observed. The conglomerates contained dividing cells, vacuoles, and leukocytes. Cell debris and sloughed germ cells were visible in the lumen of some seminiferous tubules (Figure 1E). In some cases, the peritubular wall of seminiferous tubules seemed to be affected. There were tubules with curvatures and irregularities of the wall (Figures 2D, E, black arrows) and infolding of the basement membrane toward the seminiferous tubule lumen. The invaginations were of various lengths or depths directed into the center of the lumen. Finally, invaginations of the limiting membrane with the presence of flat and elongated myoid cells were noticed (Figure 2F, yellow arrow).

The morphological changes were observed also in the interstitial tissue. The cells with strong PAS-positive material were observed in the interstitial tissue of testes, both in control (Figure 2A) and experimental (Figure 2B) rats. The number of the cells was increased in gonads of letrozole-treated rats (Figure 2B, black arrows) compared to gonads of control rats (Figure 2A, black arrow). To confirm the observation, staining with toluidine blue was carried out. It showed the cells with brown-yellow material (Figure 2C, red arrows). In our opinion, both PAS-positive cells and toluidine blue-stained cells were loaded with lipofuscin. Therefore, deparaffinized sections of testes without staining were estimated under fluorescent microscopy, taking into account the lipofuscin property to autofluorescence. The orange-red fluorescence was found in interstitial cells of experimental rats (Figure 3B, red arrows). There was no autofluorescence in cells of the seminiferous epithelium (Figure 3A). However a few cells in the interstitial tissue showed autofluorescence in control rat testis. The lipofuscin was not uniformly distributed in the cytoplasm of cells 

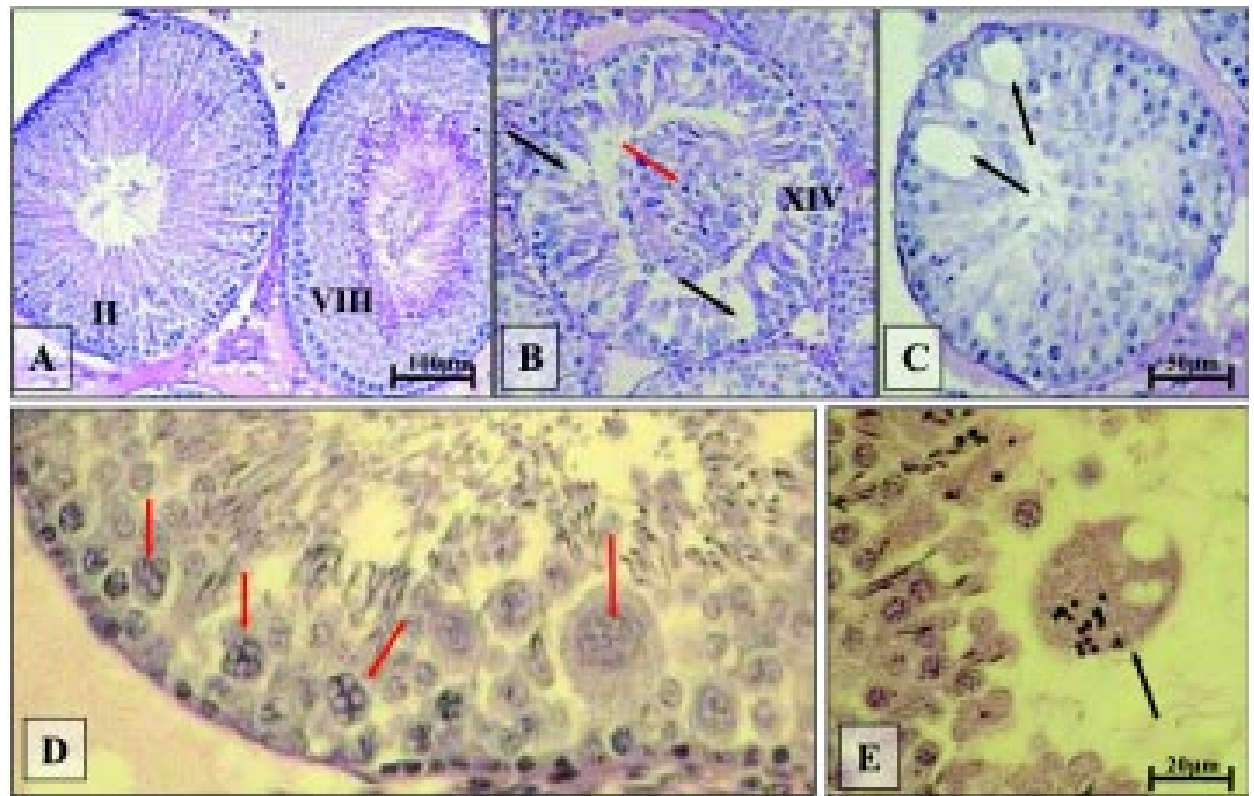

Figure 1. Cross-sections of seminiferous tubules of the testes in control (A), and experimental (B-E) rats. All germ cells generations are present, suitable for each cycle (II and VII) in the seminiferous epithelium of tubules in control rats. The sloughed premature germ cells in the lumen of tubule (red arrow) and empty areas (black arrows) after sloughed cells in the seminiferous epithelium in XIV stage of the cycle (B), the vacuolization of the seminiferous epithelium (C), multinucleated giant cells (red arrows) (D) in the seminiferous epithelium and conglomerates containing dividing cells, vacuoles, leukocytes (black arrow) in the lumen of tubule of experimental rats (E). PAS: A-C; van Gieson method: D, E. Scale bars $=100 \mu \mathrm{m}(\mathbf{A}) ; 50 \mu \mathrm{m}(\mathbf{B}, \mathbf{C}) ; 20 \mu \mathrm{m}(\mathbf{D}, \mathbf{E})$

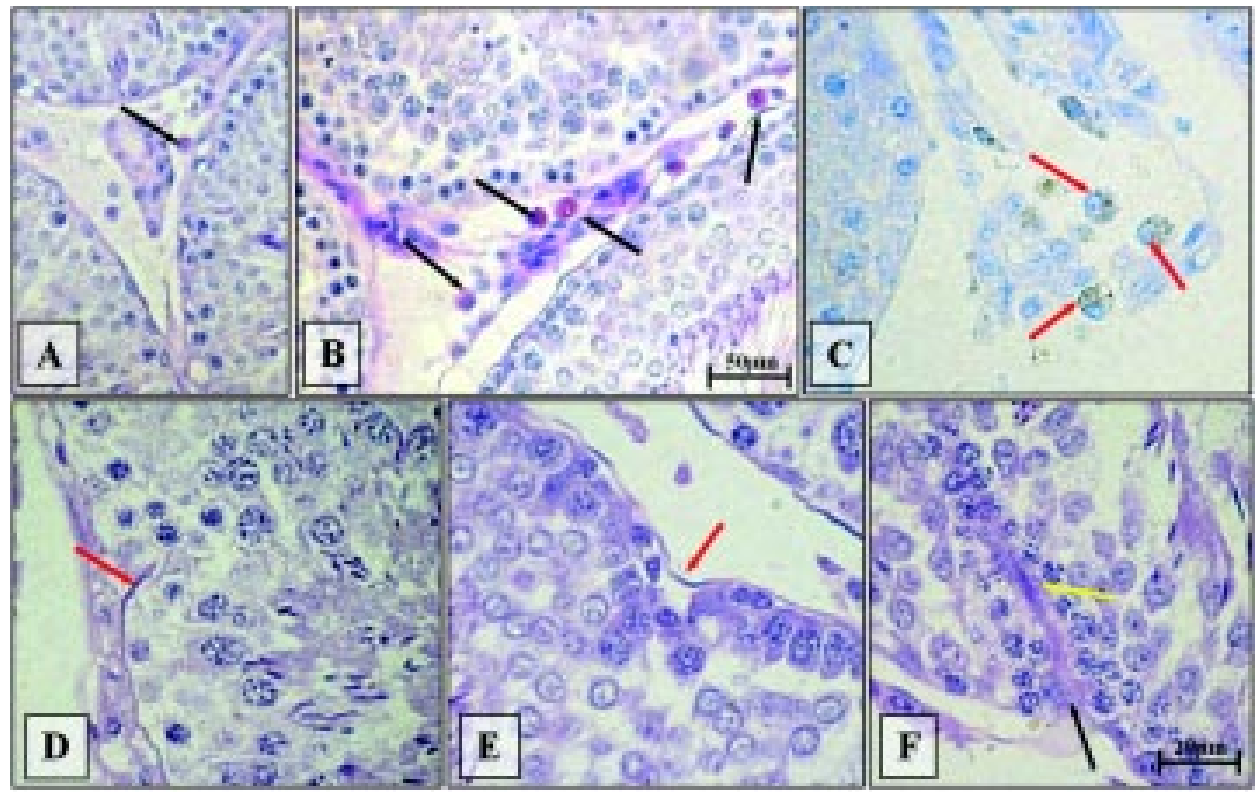

Figure 2. PAS-positive lipofuscin-containing cells in the interstitial tissue of testes in control rats (black arrows) (A) and letrozole-treated rats (black arrows) (B) and cells with lipofuscin stained with toluidine blue (red arrows) (C). Shallow (D, E) (red arrows) and deep invaginations of limiting membrane (black arrows) (F). Note the presence of nucleus of myoid cell (yellow arrow) (F). PAS: A, B, D-F; toluidine blue: $\mathbf{C}$. Scale bars $=50 \mu \mathrm{m}(\mathbf{A}, \mathbf{B}) ; 20 \mu \mathrm{m}(\mathbf{C}-\mathbf{F})$

and appeared in the form of granules of various sizes. The nucleus of the cells was eccentrically located. To distinguish if the lipofuscin-accumulating cells were really Leydig cells, the immunoexpression of $\mathrm{LH}$ receptors was performed. The cells with peripherally located nuclei displayed LH-R expression, both in control (Figures 4A, B) and experimental rats (Figures $4 \mathrm{C}-\mathrm{E}$ ) interstitial tissues. Additionally, the colocalization of red autofluorescence of lipofuscin and green fluorescence of LH-R was estimated. The orange fluorescence, indicating co-localization of lipofuscin and LH-R in the same cells was observed in 
the interstitial tissue of the control (Figure 3C, orange arrows) and in the experimental (Figure 3D, orange arrows) rats.

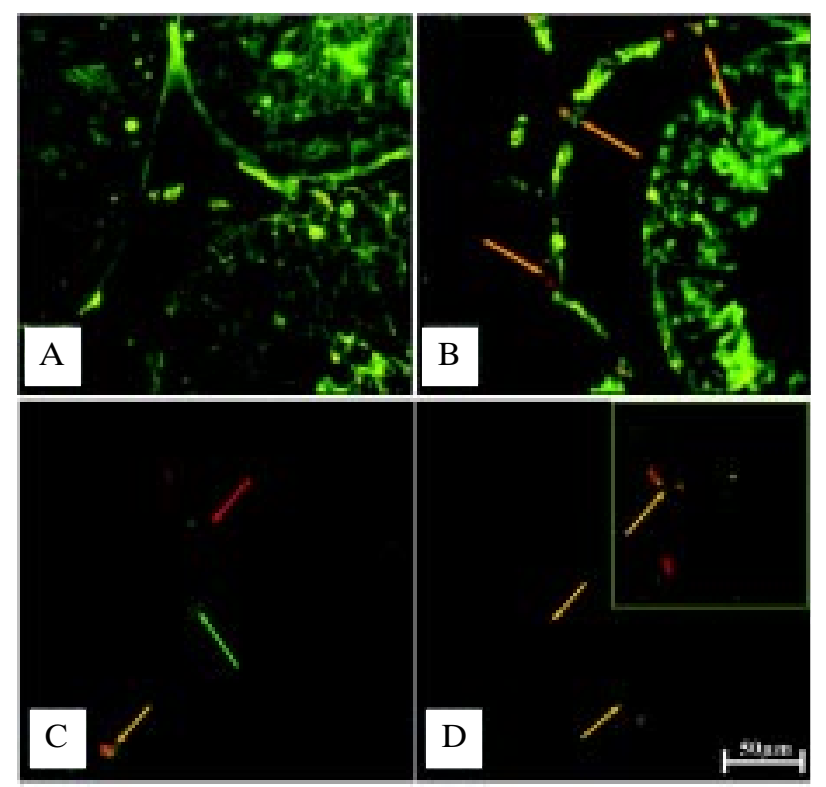

Figure 3. Cross-sections of seminiferous tubules of the testes in control (A, C), and experimental (B, D) rats. No cells with autofluorescence of lipofuscin (A) and presence of autofluorescence of lipofuscin (C, red fluorescence, red arrow) in a few cells in the interstitial tissue in control rat testes. Presence of autofluorescence of lipofuscin (red arrows) in the interstitial cells in experimental rats (B). Co-localization of orange autofluorescence (orange arrows) of lipofuscin (red fluorescence, red arrow) and LH-R (green fluorescence, green arrow) in the cytoplasm of Leydig cells in testes of control $(\mathbf{C})$ and experimental $(\mathbf{B}, \mathbf{D})$ rats. Scale bars $=50 \mu \mathrm{m}(\mathbf{A}-\mathbf{D})$
The number of interstitial cells with lipofuscin granules in testes of experimental rats was significantly higher in both PAS- and toluidine blue stained slides (26.0 \pm 14.17 and $25.8 \pm 9.66$, respectively) compared to control rats $(6.5 \pm 3.17$ and $3.3 \pm 2.9$, respectively). The differences were statistically significant: $\mathrm{p}<0.001$ (Table 2).

\section{Discussion}

In the present study, the effect of long-term estrogen deficiency on the testis morphology in adult male rats was investigated. The testicular anomalies observed by us confirmed an essential role of estrogens for normal testicular function. To produce the estrogen deficiency in male rats, we used letrozole - a third-generation inhibitor of aromatase. The letrozole structure provides a good fit with the substrate-binding site and additionally co-ordinates with aromatase heme iron and effectively inhibits the hydroxylation a reaction necessary for aromatization [25]. Because of the ability of letrozole to reduce serum estradiol concentration, it is usually used in the treatment of estrogen-sensitive breast cancer in women [26-28]. However, it is also used as a first-line treatment in hormone-sensitive male breast cancer [29, 30], and in prepubertal boys to improve final growth [31, 32].

Literature data indicates that chronic treatment with P450arom inhibitor can lead to dysregulation of testes weight, serum and intratesticular gonadotropins as well as testosterone levels [33, 34]. The aro-

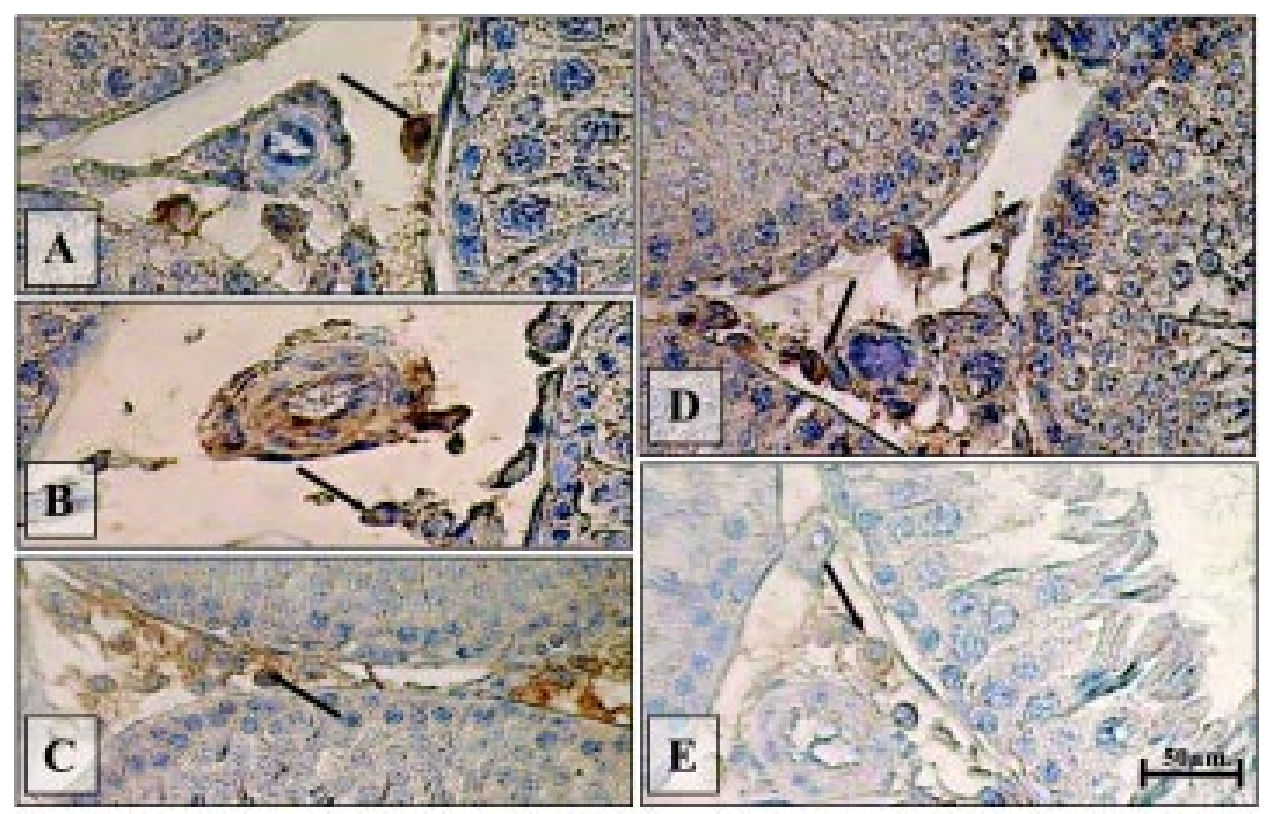

Figure 4. Immunolocalization of LH-R in Leydig cells of control (A, B) and experimental rats (C-E) (black arrows). LH-R immunoreactivity with strong intensity in the cytoplasm of Leydig cells (black arrows) in the interstitial tissue of the testes in control and experimental rats. IHC. Scale bars $=50 \mu \mathrm{m}(\mathbf{A}-\mathbf{E})$ 
Table 2. The number of interstitial cells with lipofuscin granules in slides stained with PAS method and toluidine blue

\begin{tabular}{|l|c|c|c|c|}
\hline \multirow{2}{*}{} & \multicolumn{2}{|c|}{ PAS } & \multicolumn{2}{c|}{ Toluidine blue } \\
n= 10 & 10 \\
\cline { 2 - 5 } & Control (C) & Letrozole & Control & Letrozole \\
\hline M & 5.5 & 22 & 3.5 & 23.0 \\
\hline Q1-Q3 & $4.0-9.0$ & $17.0-30.0$ & $0.0-6.0$ & $17.0-37$ \\
\hline $\mathrm{X} \pm \mathrm{SD}$ & $6.5 \pm 3.17$ & $26.0 \pm 14.17^{* * *}$ & $3.3 \pm 2.9$ & $25.8 \pm 9.66^{* * *}$ \\
\hline & & vs. C & & vs. C \\
\hline
\end{tabular}

$\mathrm{M}$ - median; Q1-Q3 - lower-upper quartiles; $\mathrm{X} \pm \mathrm{SD}-$ mean $\pm \mathrm{SD} ; \mathrm{n}=10$ areas of the interstitial tissue; vs. - versus; asterisks indicate statistically significant differences in Mann-Whitney $\mathrm{U}$ test: $* * * \mathrm{p}<0.001$

matase inhibition also affected sperm production, as has been evidenced in boars by At-Taras [35].

The levels of circulating and intratesticular estradiol were significantly decreased $(43 \%$ and $48 \%$, respectively) in letrozole-treated rats in our experiment. The long-term estrogen deficiency resulted in the morphological alternations of the seminiferous tubules and the interstitial Leydig cells in rat gonads. The presence of immature germ cells in the lumen of many seminiferous tubules was observed. Additionally, within the seminiferous epithelium, the empty spaces after sloughing premature germ cells were present.

The obtained results indicated that long-term estrogen deficiency produced the disruption of the adhesion between Sertoli cells and germ cells, and caused premature loss of germ cells. The sloughing of premature germ cells from the seminiferous epithelium was observed in our former studies with disturbances of hormonal balance caused by the inhibition of $5 \alpha$-reductase, that decreased DHT level [36] and in rats treated with soya isoflavones, that increased estradiol level [37]. Similar effects have been observed in testes of Calomys callosus chronically treated with ethanol as a result of testosterone level reduction [38] or in testes of adult rats treated with cimetidine referred as antiandrogenic agent [39]. The data indicates that germ cells sloughing is not a specific process and can be found in different hormonal disturbances.

In our study, the chronic estrogens deficiency caused other kinds of abnormalities such as the intraepithelial vacuolization and the formation of multinucleated giant cells. Similar changes have been observed by others in the testes of mice and rats after treatment with antispermatogenic agents, for instance 20,25-diazacholesterol dihydrochloride, nitrofurazone or gossypol tetra-acetic acid [40, 41], antineoplastic agents or low doses of cadmium $[42,43]$. As was mentioned by Hoffer [40], the mechanism of formation of inter- and intracellular vacuolization is not known. However, the intracellular vacuolization observed in that study arose from swelling of agranular reticulum elements and subsurface cisternae. To explain the formation of intraepithelial vacuoles observed in our study, a more detailed examination on the molecular level is needed.

Germ cells loss by apoptosis and therefore multinucleated giant cells occur normally during spermatogenesis [44-46]. The number of cells in the seminiferous tubules is determined by a dynamic balance between cells proliferation and apoptotic cell death. Any imbalance of the two processes may result in histological changes in the seminiferous epithelium [47], including the increased number of multinucleated giant cells.

The testicular alternations as germ cell sloughing, intraepithelial vacuolization, and the presence of multinucleated giant cells were accompanied with irregulation and folding of the limiting membrane and its deep invaginations into the seminiferous tubules. In some cases, the membrane was separated from the seminiferous epithelium and seemed to be disrupted. Similar invaginations were observed for the first time by Haider et al. [48] in the testes of patients with varicocele. They suggested that the basement membrane and the innermost one or two myoid cell layers participated in the formation of invaginations [48]. The invaginations observed in testis of experimental rats in our study contained one layer of myoid cells. The irregularities, infolding of the basement membrane, lamellation of the lamina densa, as well as hyperplasia of collagen fibers of the tunica propria have been described in alcohol-fed Sprague Dawley rats, in which testosterone levels in serum and testes declined [49]. A similar effect was observed in the testes of rats injected with etoposide (VP-16) used as a form of chemotherapy [50]. The basement membrane is modified extracellular matrix [51], coexisting side-by-side with anchoring junctions, such as ectoplasmic specializations and desmosome-like junctions [52-54]. Sertoli cells and germ cells at different stages of differentiation are resting on the membrane, which plays a significant role in the spermatogenesis regulation 
and maintenance of the function and dynamic of the blood-testis barrier [52-54]. It can be supposed that the invaginations observed in the testes of experimental rats could affect the functions of the seminiferous epithelium caused by blood-testis barrier damage.

Additionally, we observed changes in the structure of interstitial cells. The interstitial cells of letrozole-treated rats were rich in lipofuscin granules. The number of lipofuscin-loaded cells was significantly higher than in the interstitial tissue of control rats. Lipofuscin is often called age pigment and is considered to be a hallmark of aging [55]. The aging process includes thickening, widening and hernia-like protrusions of the basal membrane of seminiferous tubules, and the increase of lipofuscin deposits in Leydig cells [56]. Lipofuscin can be demonstrated by staining with periodic acid-Schiff (PAS-method) or utilizing an important property of lipofuscin - autofluorescence [55]. Lipofuscin is most often found in post-mitotic cells, including Sertoli cells, Leydig cells and also macrophages [57]. The interstitial tissue of the testis consists of loose connective tissue with blood and lymphatic vessels, fibrocytes, macrophages and clusters of Leydig cells. To identify the population of cells accumulating lipofuscin granules in the interstitial tissue, we carried out an IHC reaction for LH-R. Many interstitial cells with lipofuscin granules were identified as LH-R-positive Leydig cells.

It has been shown that Leydig cells in human aging testes accumulate lipofuscin granules. The cells were regarded as dedifferentiated cells in which the steroidogenic function is diminished [58]. Similar observations have been obtained in mouse aging testes, where in the cytoplasm of both macrophages and Leydig cells, lipofuscin granules were located. The progressive accumulation of lipofuscin granules resulted in the reduction of cytoplasmic organelles and finally their absence in the cytoplasm of the cells [59]. In our study, not all cells accumulating lipofuscin in the interstitial tissue can be classified as LH-R-positive Leydig cells. However, in the cells the expression of LH-R could be decreased because of the diminished steroidogenic activity. Additionally, the presence of macrophages with lipofuscin granules in the cytoplasm cannot be excluded.

In summary, long-term (six month) estrogen deficiency produced histomorphological changes in rat testes similar to that observed in the aging processes. They included the sloughing of premature germ cells, the vacuolization of the seminiferous epithelium, the formation of giant cells and conglomerates of degenerating cells, shallow and deep invaginations of basement membrane, as well as lipofuscin accumulation in Leydig cells. These results demonstrate the impor- tant role of estrogens on seminiferous tubules and the interstitial tissue morphology.

\section{References}

1. Hermo L, Pelletier RM, Cyr DG, Smith CE. Surfing the wave, cycle, life history, and genes/proteins expressed by testicular germ cells. Part 1: background to spermatogenesis, spermatogonia, and spermatocytes. Microsc Res Tech. 2010;73: 241-278.

2. Carreau S, Silandre D, Bois C, Bouraima H, Galeraud-Denis I, Delalande C. Estrogens: a new player in spermatogenesis. Folia Histochem Cytobiol. 2007;45:5-10.

3. Carreau S, Silandre D, Bourguiba S et al. Estrogens and male reproduction: a new concept. Braz J Med Biol Res. 2007;40: 761-768.

4. Carreau S, Hess RA. Oestrogens and spermatogenesis. Philo Trans R Soc Lond B Biol Sci. 2010;365:1517-1535.

5. Hess RA. Estrogen in the adult male: from a curiosity to absolute necessity. Ann Rev Biomed Sci. 2004;6:1-12.

6. O'Donnell L, Robertson KM, Jones ME, Simpson ER. Estrogen and spermatogenesis. Endocr Rev. 2001;22:289-318.

7. Rago V, Aquila S, Panza R, Carpino A. Cytochrome P450arom, androgen and estrogen receptors in pig sperm. Reprod Biol Endocrinol. 2007;5:23.

8. Baines H, Nwagwu MO, Hastie GR, Wiles RA, Mayhew TM, Ebling FJ. Effects of estradiol and FSH on maturation of the testis in the hypogonadal (hpg) mouse. Reprod Biol Endocrinol. 2008;6:4.

9. Ebling FJ, Brooks AN, Cronin AS, Ford H, Kerr JB. Estrogenic induction of spermatogenesis in the hypogonadal mouse. Endocrinology. 2000;141:2861-2869.

10. Lim P, Allan CM, Notini AJ et al. Oestradiol-induced spermatogenesis requires a functional androgen receptor. Reprod Fertil Dev. 2008;20:861-870.

11. Pentikainen V, Erkkila K, Suomalainen L, Parvinen M, Dunkel L. Estradiol acts as a germ cell survival factor in the human testis in vitro. J Clin Endocrinol Metab. 2000;85:2057-2067 .

12. Akingbemi BT. Estrogen regulation of testicular function. Reprod Biol Endocrinol. 2005;3:51.

13. Carreau S, De Vienne C, Galeraud-Denis I. Aromatase and estrogens in man reproduction: a review and latest advances. Adv Med Sci. 2008;53:139-144.

14. Carreau S, Delalande C, Galeraud-Denis I. Mammalian sperm quality and aromatase expression. Microsc Res Tech. 2009;72:552-557.

15. De Ronde, Pols HA, Van Leeuwen JP, De Jong FH. The importance of oestrogens in males. Clin Endocrinol. 2003; 58:529-542.

16. Solandre D, Delalande Ch, Durand P, Carreau S. Three promoters PII, PI.f, and PI.tr direct the expression of aromatase (cyp19) gene in male rat germ cells. J Mol Endocrinol. 2007;39:169-181.

17. Bilińska B, Schmalz-Fraczek B, Sadowska J, Carreau S. Localization of cytochrome $\mathrm{P} 450$ aromatase and estrogen receptors alpha and beta in testicular cells - an immunohistochemical study of the bank vole. Acta Histochem. 2000;102:167-181.

18. Janulis L, Bahr JM, Hess RA, Janssen S, Osawa Y, Bunick D. Rat testicular germ cells and epididymal sperm contain active P450 aromatase. J Androl. 1998;19:65-71.

19. Carani C, Qin K, Simoni M et al. Effect of testosterone and estradiol in a man with aromatase deficiency. $N$ Engl J Med. 1997;337:91-105. 
20. Herrmann BL, Saller B, Janssen OE et al. Impact of estrogen replacement therapy in a male with congenital aromatase deficiency caused by a novel mutation in the CYP19 gene. $J$ Clin Endocrinol Metab. 2002;87:5476-5484.

21. Morishima A, Grumbach MM, Simpson ER, Fisher C, Qin K. Aromatase deficiency in male and female siblings caused by a novel mutation and the physiological role of estrogens. J Clin Endocrinol Metab. 1995;80:3689-3698.

22. Smith EP, Boyd J, Frank GR et al. Estrogen resistance caused by a mutation in the estrogen-receptor gene in a man. $N$ Engl J Med. 1994;331:1056-1061.

23. Hewitt SC, Harrell JC, Korach KS. Lessons in estrogen biology from knockout and transgenic animals. Annu Rev Physiol. 2005;67:285-308.

24. Bancroft JD, Gamble M. Theory and practice of histological techniques. London; Churchill Livingstone; 2002: 151, 175, 315.

25. Miller WR. Background and development of aromatase inhibitors. In: Aromatase inhibitors. Birkhauser Verlag Berlin, Ed. BJA Furr. 2006:1-22.

26. Dunn BK, Ryan A. Phase 3 trials of aromatase inhibitors for breast cancer prevention: following in the path of the selective estrogen receptor modulators. Ann NY Acad Sci. 2009;1155:141-161.

27. Janni W, Hepp P. Adjuvant aromatase inhibitor therapy: outcomes and safety. Cancer Treat Rev. 2010;36:249-261.

28. Monnier A. Long-term efficacy and safety of letrozole for the adjuvant treatment of early breast cancer in postmenopausal women: a review. Ther Clin Risk Manag. 2009;5:725-738.

29. Arriola E, Hui E, Dowsett M, Smith IE. Aromatase inhibitors and male breast cancer. Clin Transl Oncol. 2007;9:192-194.

30. Nordman IC, Dalley DN. Breast cancer in men - should aromatase inhibitors become first-line hormonal treatment? Breast J. 2008;14:562-569.

31. Dunkel L. Update on the role of aromatase inhibitors in growth disorders. Horm Res. 2009;71:57-63.

32. Kumar H, Jayaraman M, Verma A, Modi KM. Letrozole as a booster therapy in growth hormone deficiency. Indian Pediatr. 2009;46:625-627.

33. Li X, Strauss L, Mäkelä S et al. Multiple structural and functional abnormalities in the $\mathrm{P} 450$ aromatase expressing transgenic male mice are ameliorated by a $\mathrm{P} 450$ aromatase inhibitor. Am J Pathol. 2004;164:1039-1048.

34. Turner KJ, Morley M, Atanassova N, Swanston ID, Sharpe RM Effect of chronic administration of an aromatase inhibitor to adult male rats on pituitary and testicular function and fertility. J Endocrinol. 2000;164:225-238.

35. At-Taras EE, Berger T, McCarthy MJ, Conley AJ, Nitta-Oda BJ, Roser JF. Reducing estrogen synthesis in developing boars increases testis size and total sperm production. $J$ Androl. 2006;27:552-559.

36. Kolasa A, Marchlewicz M, Wenda-Różewicka L, Wiszniewska B. Morphology of the testis and the epididymis in rats with dihydrotestosterone (DHT) deficiency. Rocz Akad Med Bialymst. 2004;49:117-119.

37. Piotrowska K, Baranowska-Bosiacka I, Marchlewicz M et al. Changes in male reproductive system and mineral metabolism induced by soy isoflavones administered to rats from prenatal life until sexual maturity. Nutrition. 2011;27:372-379.

38. Martinez M, Macera S, De Assis GF et al. Structural evaluation of the effects of chronic ethanol ingestion on the testis of Calomys callosus. Tissue Cell. 2009;41:199-205.

39. Sasso-Cerri E, Cerri P. Morphological evidences indicate that the interference of cimitidine on the peritubular components is responsible for detachment and apoptosis of Sertoli cells. Reprod Biol Endocrinol. 2008;6:18.

40. Hoffer AP. Effects of gossypol on the seminiferous epithelium in the rat: a light and electron microscope study. Biol Reprod. 1983;28:1007-1020.

41. Singh SK, Chakravarty S. Antispermatogenic and antifertility effects of 20,25-diazacholesterol dihydrochloriede in mice. Reprod Toxicol. 2003;17:37-44.

42. Vendramini V, Sasso-Cerri E, Miraglia SM. Amifostine reduces the seminiferous epithelium damage in doxorubicintreated prepubertal rats without improving the fertility status. Reprod Biol Endocrinol. 2010;8:3.

43. De Souza Predes F, Diamante MA, Dolder H. Testis response to low doses of cadmium in Wistar rats. Int J Exp Pathol. 2010;91:125-131.

44. Allan DJ, Harmon BV, Roberts SA. Spermatogonial apoptosis has three morphologically recognizable phases and shows no circadian rhythm during normal spermatogenesis in the rat. Cell Prolif. 1992;25:241-250.

45. Boekelheide K, Fleming SL, Johnson KJ, Patel SR, Schonefeld HA. Role of Sertoli cells in injury-associated testicular germ cell apoptosis. Proc Soc Exp Biol Med. 2000; 225:105-115.

46. Sinha Hikim AP, Swerdloff RS. Hormonal and genetic control of germ cell apoptosis in the testis. Rev Reprod. 1999; 4:38-47.

47. Chen Y, Zuo Z, Chen S et al. Reduction of spermatogenesis in mice after tributyltin administration. Toxicology. 2008;251:21-27.

48. Haider SG, Passia D, Servos G, Hettwer H. Electron microscopic evidence for deep invaginations of the lamina propria towards the seminiferous tubule lumen in a patient with varicocele. Int J Androl. 1986;9:27-37.

49. Shirai T, Ikemoto I. Mechanism of alcoholic testicular damage. Nippon Hinyokika Gakkai Zasshi. 1992;83:305-314.

50. Kadota T, Chikazawa H, Takahashi N. Toxicological study of etoposide (VP-16) in rats with special emphasis on testicular alteration. Toxicil Lett. 1989;45:185-194.

51. Dym M. Basement membrane regulation of Sertoli cells. Endocr Rev. 1994;15:102-115.

52. Siu MK, Cheng CY. Extracellular matrix: recent advances on its role in junction dynamics in the seminiferous epithelium during spermatogenesis. Biol Reprod. 2004;71:375-391.

53. Siu MK, Cheng CY. Dynamic cross-talk between cells and the extracellular matrix in the testis. Bioessays. 2004;26: 978-992.

54. Siu MK, Cheng CY. Extracellular matrix and its role in spermatogenesis. Adv Exp Med Biol. 2008;636:74-91.

55. Terman A, Brunk UT. Lipofuscin. Int J Bioch Cell Biol. 2004;36:1400-1404.

56. Sampson N, Untergasser G, Plas E, Berger P. The ageing male reproductive tract. J Pathol. 2007;211:206-218.

57. Terman A, Brunk UT. Lipofuscin: mechanism of formation and increase with age. APMIS. 1998;106:265-276.

58. Paniagua R, Amat P, Nistal M, Martin A. Ultrastructure of Leydig cells in human ageing testes. J Anat. 1986;146: 173-183.

59. Giannessi F, Giambelluca MA, Scavuzzo MC, Ruffoli R. Ultrastructure of testicular macrophages in aging mice. J Morphol. 2005;263:39-46.

Submitted: 13 December, 2010 Accepted after reviews: 1 May, 2011 